\title{
TERRITORIAL CONSOLIDATION REFORMS \\ - EUROPEAN EXPERIENCES OF 21ST CENTURY
}

DOI: http://dx.doi.org/10.18509/GBP.2015.48

UDC: 342.5.047(4-672EU),,20“6

\section{Prof. Pawel Swianiewicz}

University of Warsaw, Department of Local Development and Policy, Faculty of Geography and Regional Studies

\begin{abstract}
The last decade has brought re-invigorated discussions about territorial reforms in numerous European countries. The intensity of the reforms has especially grown with the beginning of economic turn-down in 2008, since several countries perceived territorial reforms as an element of cost-saving and austerity measures. The paper discusses experiences of reforms implemented after 2000 in Albania, Georgia, Greece, Denmark, Finland, Ireland, Latvia, Macedonia and Netherlands, with an emphasis on the reforms in two Balkan countries. Most of reforms were rooted in economy of scale paradigm suggesting that larger scale of territorial units may support both lowering of unit costs and quality of local government performance in service delivery. The impact on local democracy has not been part of the main discourse, and it was practically disregarded in some of the countries.
\end{abstract}

Keywords: territorial reform, economy of scale, local democracy, local government

\section{INTRODUCTION}

Europe remains a continent with highly diversified models of territorial organization on a basic level of local government. On the one extreme there are countries with very large municipalities - such as England or Ireland (with mean population size of local government well above 100,000) as well as Denmark, Finland, Lithuania or Georgia with average size of municipality being over 50,000 citizens. On the other extreme there are territorially fragmented countries with several thousand of small local governments, where usually each settlement unit has its own local government. France with its over 30,000 communes is the best known example of such a system, but we may add Czech Republic, Slovakia, Hungary, Switzerland, Ukraine or Spain to that list. In all of these countries the mean population size of local government is less than 5,000, and in case of French, Czech or Slovak communes it is even below 2,000.

Although there are some arguments (usually referring to local democracy principles - for recent review see [3]) in defense of such territorially fragmented systems, the small size of local government units is very often seen as a barrier for efficient and effective delivery of public services to local communities.

Theoretical arguments of proponents of territorial fragmentation and consolidation developed during the debates on territorial organization of the management of metropolitan areas. Arguments of proponents of territorial consolidation are often summarized as "reform theory", while proponents of the fragmentation are identified with public choice theory and related arguments of "voting by feet". Perhaps the most comprehensive summary of theoretical discussion may be found in the paper by Keating [5] who indicates four major dimensions of the discussion on optimal size of territorial units: 
- economic efficiency of service delivery

- quality of local democracy

- distribution of resources (and level of inequalities among local governments)

- capacity to implement local economic development policies.

As far as relationship between the size and service provision is concerned, the dominant tune of international academic literature may be summarized in the following conclusions:

- larger local governments have usually more capacity to provide wide range of services. Consequently, territorial consolidation makes functional decentralization more likely to happen;

- economy of scale may be found not only in industry, but also in provision of several public services (the most frequent evidences are related to administrative spending). Therefore larger territorial scale allows for cheaper service delivery;

- in territorially consolidated systems it is easier to reduce the "free-ride effect" in service delivery (situation in which citizens/ tax payers from other local jurisdictions benefit from locally produced services). Obviously, the extent of "free riding" depends also on the scope of locally delivered services, so territorial consolidation allows for more functions allocated to local level;

- discussions of the impact of size on efficiency of local services' delivery are more difficult and often controversial. There is a basic methodological problem with measuring the output of services, and there is certainly no objective method to measure benefits from them. In practice, many researches adopt a simplified method measuring just cost-side and follow the silent assumption that the level of service provision is invariant.

However not all research confirm the same relationship. Such a skepticism towards simple "economy of scale belief" is present e.g. in some of the World Bank Reports, which come to the conclusion that population size is not a decisive variable in determining the cost or quality of public services. They claim that where populations are geographically dispersed, there are few economies of scale to be gained by incorporating them into a single large jurisdiction [4].

The relationship between size and local democracy is even more complex. Denters at al [3], using the terms which may be found in Jonathan Swifts novel Gulliver's Travel formulate three hypothesis: Lilliput argument, Brobdingnag argument and social context hypothesis, according to which what matters is not the size itself but the social context (e.g. social structure of local communities), which is often different in jurisdictions of different sizes. The Lilliput argument suggests that in small jurisdictions contacts between citizens and local politicians as well as bureaucrats are closer. Social trust is based on strong personal ties, decline of community and social trust resulting from increasing scale will be reflected in declining political trust. This high trust should subsequently be reflected in general positive attitudes towards the elected officials in small units. In small communities there is also more incentive for citizens participation because a single individual's vote will "weight more". This rational argument is additionally strengthened by more socio-psychological argument that people are more likely to develop a stronger sense of community and local identification in smaller, more homogenous settings. This in turn will heighten interest in local affairs and stimulate political involvement. From 
"voting by feet" model one can draw a conclusion that in smaller communities, due to their homogeneity, it is easier to close a gap between implemented policies and individual preferences.

But on the other hand (Brobdingnag argument), as large local governments may provide more functions, it leads to more public interest and participation in local politics [2]. The theory argues that broader list of functions also helps to attract "better quality" candidates to local councils. It is also related to the fact that power and prestige associated with office in larger constituencies is greater. Territorial consolidation provides also more space for organized interest groups representing pluralist society, which helps to avoid domination of the one, narrow local elite. In big communities it is easier to avoid nepotism or other forms of political clientelism.

Both of the claims are sometimes challenged by authors who suggest size of local government is far less important for various dimensions of the quality of government than is generally presumed. In spite of numerous empirical analysis it is difficult to formulate final conclusions.

Nevertheless, proponents of "economy of scale" paradigm often prevail in governments' administrations. Therefore, territorial amalgamation reforms are very hot political issues and there have been many attempts of implementation such reforms in recent years. Territorial reforms were subject of several academic research ([1], [7], [10]). They all stress that territorial amalgamation reforms are always very difficult. There are several reasons for that difficulty, but one very simple is that "turkeys never vote for Christmas" - there is usually a very strong opposition of politicians from local governments which may be abolished as separate units. One should add to these frequent fears of local communities who are afraid of losing identity by their villages and of more distant administrative and other services. That is why it is not surprising that there are many examples of failed attempts at such reforms. Such a list includes earlier attempts in Norway, Estonia, failed Albanian reform in 2003 or in Ukraine 2004. In countries such as France, Spain, Hungary, Slovakia or Czech Republic territorial reform is seen as politically impossible, so no one dares even to try it, in spite several experts suggest that it would be required.

\section{TERRITORIAL REFORMS IN EUROPE - A BRIEF OVERVIEW}

But in spite of all political and technical difficulties a spectre is haunting Europe - the spectre of territorial reforms.

There are several examples of European countries which successfully implemented territorial amalgamation reforms after the Second World War. The first wave of territorial consolidations took place in $1950^{\text {th }}-1970^{\text {th }}$ and involved Scandinavia, UK, Netherlands and lands of West Germany. In the similar period there was a parallel set of territorial consolidation in the communist part of Europe (Czechoslovakia, Hungary, Poland, Romania, Yugoslavia). The second wave of territorial amalgamation may be noticed much more recently - in recent ca. 20 years. The trend has even accelerated in a response to the economic slowdown of 2008. Although empirical evidences are not totally convincing, there is a frequent believe that creation of the more territorially consolidated system may help to save money spent on local administration and local public services. The list of countries which implemented territorial amalgamation of the municipal tier within last 20 years includes: 
- Lands of East Germany (different years in different lands)

- Greece (1999, with the second step of amalgamation in 2011)

- Macedonia (2002)

- Georgia (2006)

- Denmark (2007)

- On-going, continuous amalgamation changes in United Kingdom (through creation of unitary authorities in England but also plans for further amalgamation in Wales and Northern Ireland)

- Continuous year by year cases of mergers in Netherlands and Finland

- Latvia (2009)

- Ireland (2014)

- Albania (2014-2015).

There are also on-going discussion in some other countries - including Ukraine, Armenia, most recently Norway. There is also a slowly emerging discussions of that issue in Poland.

In this paper I briefly discuss two recent cases in a broadly understood Balkan region: Macedonian reform of 2002 and Albanian reform of 2014.

\section{TERRITORIAL REFORM IN MACEDONIA, 2002}

Macedonian territorial reform, as many other reforms in Eastern and Central Europe, had one specific important actor, namely international community of foreign donor programmes. They played an important role in territorial reforms implemented in Georgia 2006 and Albania 2014 (the case which is discussed later on in the paper). Foreign experts are not involved in local power games, so it is relatively easy for them to formulate radical proposals. Sometimes they treat their work abroad as an occasion to test theories, which might be more difficult to test in their home countries.

Talking about Macedonian reform one should start from disintegration of Yugoslavia and emergence of the new independent states in 1991. Former Yugoslav local governments were rather big, and Macedonia was divided into just 30 local government units. The new territorial system, implemented in 1995 introduced 125 local governments, which mean than on average an "old municipality" was divided into four new territorial units. The next reform was implemented in 2002-2004 after the tragic civil war and was an element of Ohrid Agreement. One element of the change was reduction in the number of local governments to 84 . Technically speaking, it was a territorial consolidation reform, but taking onto account an earlier situation (during Yugoslav period) it was just a partial reverse of the territorial fragmentation of the previous decade. Increasing financial potential of local governments and enlarging their capacity to provide more service functions were among official goals of the reform [6]. But ethnic policy was very much in the background of the whole reform process. Wider decentralization was one of the conditions of the agreement which helped to stop the civic war between Macedonians and Albanian minority. The Ohrid agreement stipulated that in cases in which more than $20 \%$ of local residents belongs to ethnic minority (the most often Albanian, but the same 
concerned Vlachs, Turks and other minorities), the minority language will be used as second official.

The debate on details of the new administrative map has often concentrated around attempts of Macedonian and Albanian ethnic parties to establish new borders in a way which would give them majority (or at least no less than $20 \%$ minority) in as many new local governments as possible. As Kreci and Ymeri ([6]) calculated, as a result of that process $79 \%$ of Albanians and $93 \%$ of Macedonians lives in municipalities in which their ethnic group is a clear majority.

Implementation of the reform was preceded by popular referendum, organized in spite of the protest of nationalist political parties.

\section{TERRITORIAL REFORM IN ALBANIA - 2014}

Albania provides a case of perhaps the youngest of European territorial reforms. It is still in the process of implementation - the Parliament adopted the new territorial organization in July 2014, and the new local governments would become operational during 2015. The first attempt of reform was made in 2003, but the government majority was not sufficient to enforce the reform in spite of disagreement of the opposition. Political change after next Parliamentary election has frozen plans of the reform for nearly decade. The idea came back after Socialist Party victory in general election on Spring 2013. The new Prime Minister was a former mayor of Tirana, and the new Minister for Local Governments a person, who was working on the concept of 2003 reform. The plans of the reform were announced late summer of 2013. And preparatory works, with the support of several foreign donor programmes, started in Autumn 2013. In additional to typical arguments, which may be found in other countries as well, the specific Albanian challenge has been related to the intensity of demographic change. Strong emigration to other countries (mostly Italy and Greece) together with internal migrations from distant, rural regions to big cities (mostly to Tirana agglomeration) has led to fast depopulation of some regions in the peripheries. Comparison of 2001 and 2011 national censuses indicates numerous local governments which lost over half of its population during one decade. In one, extreme case the decrease was as big as 90\% (from 3,000 population in 2001 to just 300 in 2011). Such a rapid demographic change has indeed challenged the rationale of the old administrative organization.

In spite of the skeptical opinions of some experts (and of the opposition parties), the Albanian government has decided for very radical variant of amalgamation. Number of local government units was reduced from 370 to 61 . The mean population size of local government increased from 7,000 to ca. 45,000. The number or regions (quarks) has remained unchanged so far (12), as their status of representatives of basic level governments. The decision of delaying regional reform was mostly related to the constitutional provisions on regions, which would need to be changed. The law introducing a new map was voted in July 2014, it was signed by the President at the end of August and the reform would be completed by 2015 local elections. There are couple of issues related to the reform which call for the careful skepticism related to the expected effects of the change:

- Political environment - Albanian political stage is highly polarized and the government was unable to reach an agreement with the main opposition party. As a result, opposition boycotted works of the special Parliamentary committee and the 
final voting in the Parliament. It is not a good prognosis for the stability of territorial arrangements in case of possible future political changes on a central level.

- Information - accessibility of more sophisticated data necessary for simulation of various options and their potential impact was rather poor. Several variables were unavailable, and some of the reformers seemed not to understand the threats related to that issue.

- Analytical - even the limited set of available data allowed for analysis, which suggested misinterpretation of some diagnosis made by the reforms and suggested that potential gains from the reform might not be as big as promised (and expected) by the proponents of the reform. Some of analysis indicated that weaknesses of small communes (to which the reform was supposed to be a remedy) are partially related to not their size itself, but rather to peripherial location (see [11]). It is not very surprising; similar results were earlier available in several analysis performed in various countries discussing amalgamation reforms [4]. But methodologically sophisticated analysis of available data did not bring huge interest of politicians and central government administration. And skeptical opinions were often ignored in further discussions. But to be fair, it is important to add that proponents of the reform tried to consider potential negative side-effects of the reform and introduce measures to minimize such unwanted impacts.

- In spite of declared comprehensive approach, there is still no satisfactory connection between territorial and other local government reforms (functional and financial reforms). It seems that there is a general belief that the territorial change itself may be sufficient to solve several issues. Earlier experiences, such as of Georgian 2006 reform [12] demonstrate that lack of comprehensiveness may undermine the success of the whole reform.

- Radical change - very radical character of the territorial change (although one should remember about even more radical options discussed in 2014, e.g. the map proposal assuming just 30 large local governments in the country) may result in serious social problems especially in sparsely populated, mountain regions, in which transport accessibility to the new local centres is very poor.

\section{CONCLUDING REMARKS}

Figure 1 demonstrates the result of amalgamation reforms implemented in various European countries during the last decade. As one may notice, the territorial reforms have been implemented not only in countries with very small local government units (Greece, Latvia, Georgia), but sometimes also in countries in which local governments were relatively big even before the change (England, Ireland, Netherlands, Denmark). 
Fig. 1.

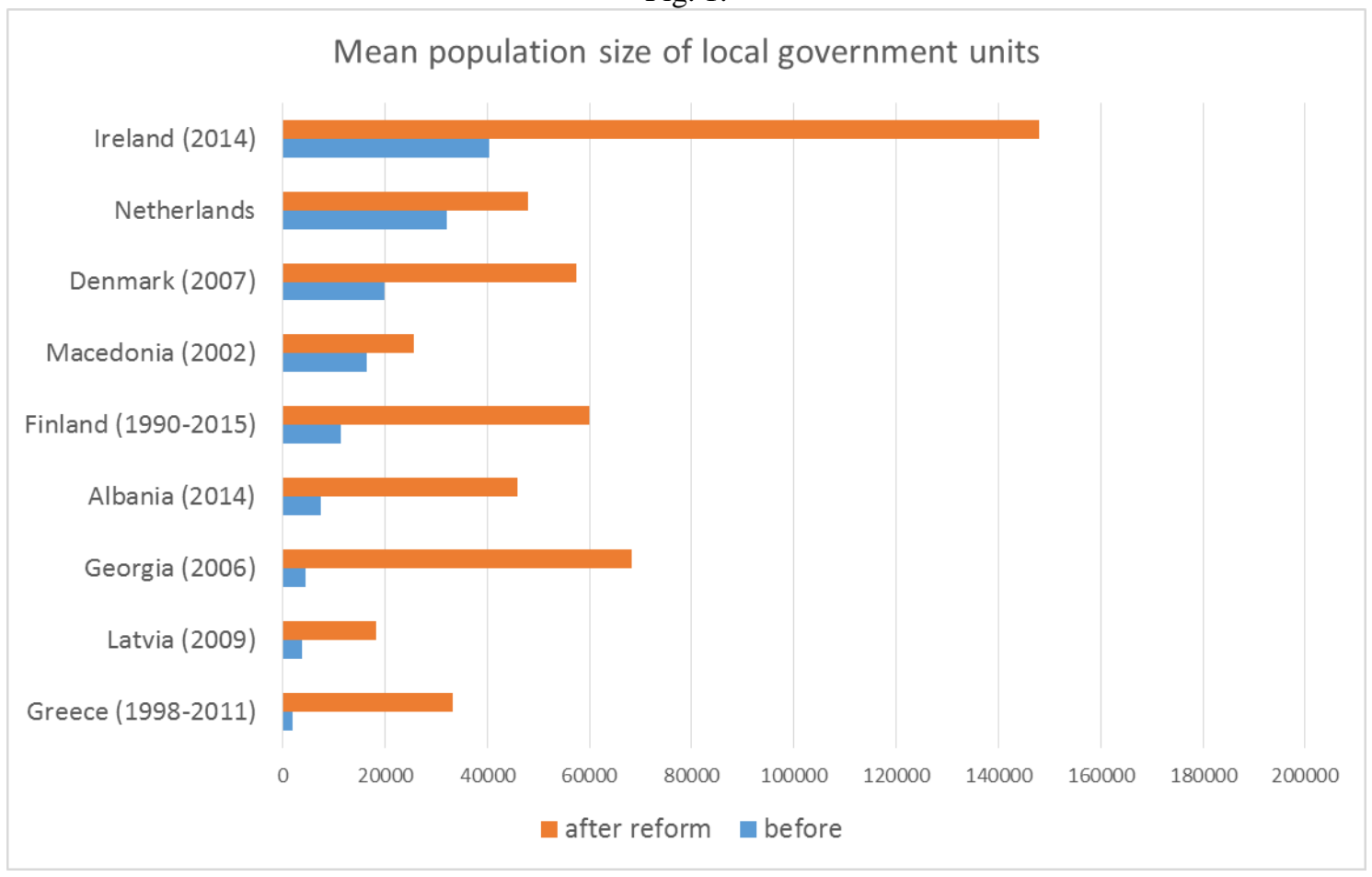

Analysing reforms which have been actually implemented, one may notice that there were two basic modes of implementation:

- a single-shot exercise, in which the reform was introduced as top-down government (parliament) decision imposed on local communities. That was usually preceded by extensive public debates and consultations, but the reform itself was introduced by a single decree.

- a two-steps method, in which the first step was semi-voluntary - local governments reacted with their own reform proposals as a response to general criteria suggested by central government.

Interestingly, such a semi-voluntary model was tried in several countries. In some it failed - there was no satisfactory response from local governments (e.g. Greece, Latvia - which later decided for compulsory top-down change, some other countries of Eastern and Central Europe in which the reform has never happened so far). But in some countries the two-stages method worked well - e.g. Denmark, some the German lands, Finland, Netherlands. Each of these cases tells its own different story, but can we try to summarize conditions which make "turkey voting for Christmas" (i.e. semi-voluntary agreeing for mergers with neighbouring locality) more likely? It seems that there are following important factors supporting success of the voluntary amalgamations (while their lack increases probability of the failure of that method):

- Trust in stable government policy and determination in the implementation. If local governments are convinced that there is "no other choice", and that the change will affect them sooner or later anyhow, they are more inclined to look for voluntary solutions. But if those who are afraid of changes hope that the political determination may evaporate before the second stage is completed (or that the government may change in between to one which is less determined) they would probably delay the change and wait for resignation from the ambitious plan. 
- Consensual political culture makes semi-voluntary changes more likely than majoritarian one. Early consultation of the reform plans (on the very early stage of its design) with various political forces is also part of that condition. Danish reform provides perhaps the best example of such an approach, although Dutch and Finnish cases are not very far from such situation either.

- High level of bridging social capital among political elites and local communities which allows for higher level of trust - among communities to be merged, among local politicians, between central and local governments etc.

- High level of local autonomy and wide scope of functional responsibilities, which helps local governments to realize that performance challenges cannot be met without a change.

- Clear incentives for the change provided by the central level (they might be of a financial nature or functional - e.g. offering wider autonomy or additional powers to those who undertake the change).

There are at least two more conditions of the successful territorial reform:

- It cannot be limited to territorial dimension only. What is essential is integration of functional, financial and territorial reforms, so all of the elements fit with each other. The lack of such an integration may be seen as one of the main factors contributing to the eventual failure of the reform (even if the "map" is changed the reform does not bring desired outcomes). 2006 Georgian reform brings a convincing example here [12]. Technically speaking it was successful in that sense that "the map" was changed as it was proposed. But because no parallel changes related to financial or functional decentralization, it brought not much more than disappointment.

- On a political level the main risk is that the reform preparation may take sufficiently long for "window of political opportunity" to be closed before the reform Is implemented. It has to be remembered that it is almost a law of local boundary restructuring, that there will be powerful forces intent on maintaining the status quo [9]. The experience of other countries suggest that too long preparation may lead to loosing political momentum. Bureaucracies do not like big reforms, so as Danish scholar P.E. Mouritzen [8] said: the war has to be won before natural enemies can mobilize themselves to block the reform. Therefore there is a clear trade-off before carefulness of content preparations and using the moment when political window of opportunity is open.

\section{REFERENCES}

[1] Baldersheim, H. \& Rose, L. Territorial Choice: The Politics of Boundaries and Borders, London: Palgrave-Macmillan, 2010.

[2] Dahl, R. \& Tufte, E.R., Size and Democracy, Stanford University Press, 1973.

[3] Denters, B., Lander, A., Mouritzen, P.E., Rose, L. Size and Local Democracy, Cheltenham-Northampton: Edward Elgar, 2014.

[4] Fox, W.F., Gurley, T. Will Consolidation Improve Sub-National Government, Policy Research Working Paper 3913, Washington: World Bank Report, 2005.

[5] Keating, M. „Size, Efficiency and Democracy: Consolidation, Fragmentation and Public Choice" [w:] D. Judge, G. Stoker, H. Wolman (eds.) Theories of Urban Politics, Sage, London- Thousand Oaks - New Delhi, 1995. 
[6] Kreci, V. \& Ymeri, B., Conceptualizing Territorial Reorganization Policy Interventions in the Republic of Macedonia, [in:] P. Swianiewicz (ed.) Territorial Consolidation Reforms in Europe, Budapest: LGI/ Open Society Institute, 2010.

[7] Meligrana, J. Redrawing Local Boundaries: An International Study of Politics, Procedures, and Decisions, Vancouver - Toronto: UBC Press, 2004.

[8] Mouritzen, P.E. "The Danish Revolution in Local Government: How and Why?" [in:] Baldersheim, H. \& Rose, L. (eds.) Territorial Choice: The Politics of Boundaries and Borders, London: Palgrave-Macmillan, 2010.

[9] Paddison, R. "Redrawing Local Boundaries: Deriving the Principles for Politically Just Procedures" [w:] J. Meligrana (red.) Redrawing Local Boundaries: An International Study of Politics, Procedures, and Decisions, Vancouver - Toronto: UBC Press, 2004.

[10] Swianiewicz, P. (ed.) Territorial Consolidation Reforms in Europe, Budapest: LGI/ Open Society Institute, 2010.

[11] Swianiewicz , P. Reformy terytorialne - europejskie doświadczenia ostatniej dekady, Samorząd Terytorialny, 2015 (in print)

[12] Swianiewicz, P. \& Mielczarek, A. "Georgian Local Government Reform: State Leviathan Redraws Borders?”, Local Government Studies, vol. 36(2): 291-311, 2010. 
